\title{
Beata Milewska
}

Faculty of Finance and Banking, WSB University in Poznań, Poland

\section{SUPPLY CHAIN MODELS IN GARMENT INDUSTRY}

\begin{abstract}
The paper presents the results of the study concerning supply chain models which was conducted by the author in Polish garment industry enterprises. The goal of the paper was to identify the types of supply chain models in this sector. The research methods were interviews and direct observations of manufacturing and logistics processes in clothing companies. Four types of supply chains models were characterized on the examples of supply chains of various companies. The criteria taken into consideration when characterizing the models included but were not limited to: the supply chain leader, the manufactured products (mass or individualized), the material flow strategy (push, pull), and the geographical location of the supply chain nodes. The factors differentiating these models were related to competitiveness - first of all, the price, the quality of products and services, the time of delivery, the accessibility of products, the extent of the product range.

Keywords: supply chain strategies, garment industry, supply chain models
\end{abstract}

\section{Introduction}

The term 'supply chain' can be defined in different ways (Ciesielski, Długosz, 2010; Szymoniak, 2010). In this paper it is understood as enterprises linked with one another, between which there is a flow of commodities - raw materials, semi-products, final products, information and funds connected with them (Witkowski, 2010). On the one hand, there are suppliers and sub-suppliers, on the other hand - recipients of these goods and trade intermediaries but also service companies cooperating with them - this is the so called extended supply chain (Hugos, 2011).

In the garment sector, the extended supply chain comprises manufacturers of thread, textiles and knitwear, manufacturers of garments (sewing factories), 
distributors, clothing shops, but also subcontractors in such areas as dyeing of fabrics, embroidery and transport or logistics companies, etc.

Cao et al. studied (2008) the coordination practices in different textile and apparel supply chains in Hong Kong. According to the results of these studies, supply chains are generally coordinated by brand owners. This issue was also a subject of the studies carried out by the author of this paper. A general model of a supply chain in the garment industry is presented in Figure 1.

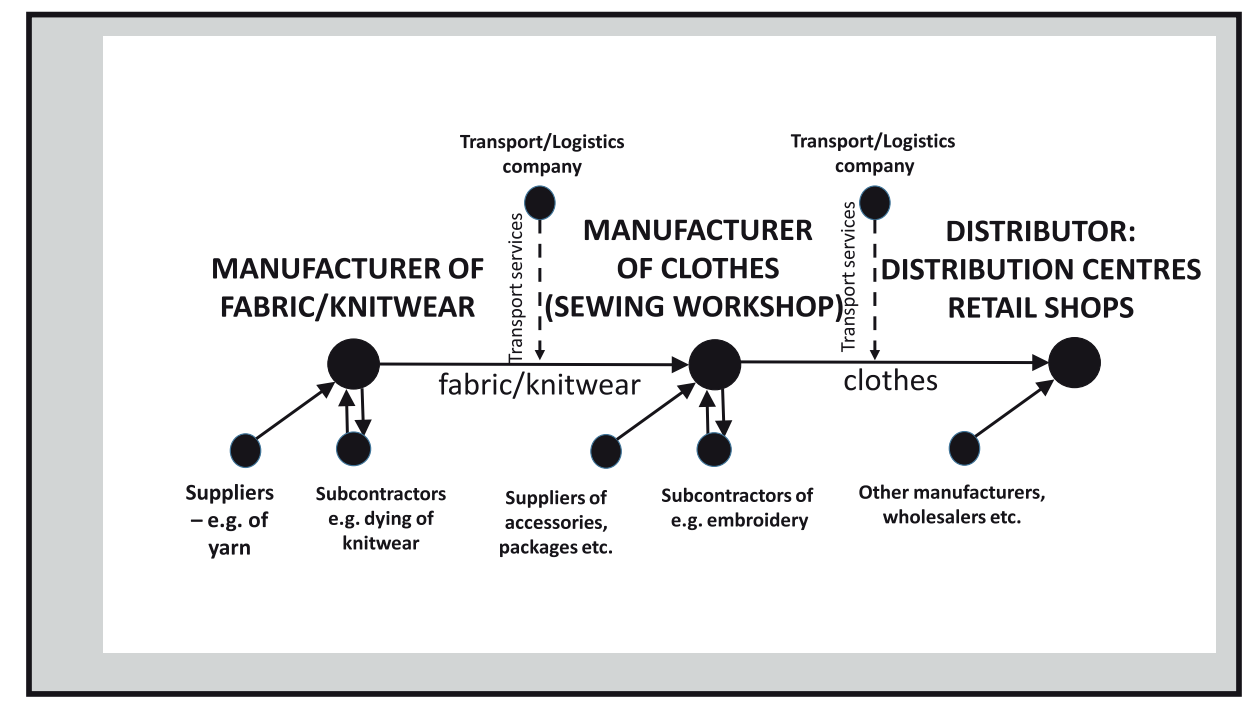

Figure 1. A general model of a supply chain in the clothing industry

Source: (own elaboration)

The paper presents the results of the research conducted by the author in the period between July 2017 and March 2018 in 15 companies from the garment industry ${ }^{1}$. Interviews were conducted with these enterprises and field research was carried out by observation of manufacturing and logistics processes. In the first part of the paper the theoretical background is presented including the criteria for the division of supply chains resulting from the study. In the following sections four types of models of supply chains in the garment industry are described - each on an example of one of the studied enterprises. In the final part a comparison of the models is made including competitiveness factors.

1 Research conducted as part of the research project: "Modern methods of managing production and logistics processes and their impact on competitiveness on the example of the clothing industry" at the Faculty of Finance and Banking of the WSB University in Poznan. 


\section{Criteria for division of supply chain models in the garment industry}

Creating supply chains is linked with making certain strategic decisions. These include but are not limited to (Ciesielski, 2009):

- Selection of suppliers, distributors and transport or logistics operators;

- Location of factories, warehouses, distribution centres;

- Distribution point and type of flow of materials and goods in the supply chain (pull, push);

- Relationships between participants in the supply chain (partnership, competition).

The logistics strategies of supply chains are formed by various factors, such as the nature of the demand (stable or variable), total delivery time, competition in the industry (price competition, product quality, logistic customer service level) and product characteristics (standard products or individualized) (Ciesielski, 2009; Ciesielski, Długosz, 2010).

These decisions and factors can be treated as criteria characterizing supply chains. The following criteria have been adopted in this article to identify the types of supply chains in the clothing industry:

- Supply chain leader - the manufacturer or an outsourcing company;

- Manufactured products - mass or individualized;

- Flow of materials - sections with the push or pull type flows;

- Location of main warehouse stocks in the supply chain;

- Geographical location of supply chain members, e.g.:

- production - in low-cost countries, regionally or locally;

- distribution centres and stores.

Based on the adopted criteria, different types of supply chain models can be distinguished. This article will describe four typical models, on the example of supply chains for specific enterprises.

\section{A supply chain model for mass production with a manufacturing outsourcing leader on the example of LPP S.A. ${ }^{2}$}

LPP S.A. is the largest clothing company in Poland, designing, distributing and selling clothes under five recognizable brands - Reserved, Cropp, House, Mohito and Sinsay - in 20 countries. The sales network covers the whole of Poland and countries of Central and Eastern Europe; stores are located also in Germany, the United Kingdom, the Balkans and the Middle East. LPP S.A. earns revenues of almost EUR 1.4 billion. The company has been listed on the Warsaw Stock Exchange since 2001, and in 2014 it was included in the WIG20 index (http://www. lpp.sa.com).

2 Based on information obtained at the LPP S.A. Logistics Center in Pruszcz Gdański in December 2017. 
LPP S.A., as a leader in the supply chain, commissions the production of a specific quantity of clothing products according to its own designs and under its own brands to external companies. Therefore, it does not have its own manufacturing plants. It outsources the manufacture of clothing:

- in the low-cost countries (Far East - mainly Bangladesh and China);

- locally or regionally (mainly in Poland and Turkey).

Currently, LPP S.A. strives to increase the share of products manufactured in Poland. Every year, Polish companies are commissioned to manufacture increasingly more clothes - it was already 5 million pieces in 2017. However, compared to the total sales of LPP S.A. (140 million items per year), this is still a small percentage.

The clothes, both manufactured in the low-cost countries, as well as locally or regionally, go to the Logistics Centre in Pruszcz Gdański. The transport time by sea from Asia to Gdańsk is about 30 days. In cases where the priority is to shorten the delivery time, LPP S.A. also uses air transport. The transport time from countries with low production costs is shortened to 7-10 days in this case. Apart from that clothes sewn in Poland and Turkey arrive to the Centre by road transport.

LPP S.A. sells its products in its own stores. There are over 1700 of them in Poland and in 20 other countries, mainly in Europe. All stores are linked to the Logistics Centre by an IT system, thanks to which information about sales in particular stores is available on an ongoing basis. Orders for individual stores (according to indexes - model, colour, size) are generated centrally. Therefore, stores do not place orders on their own.

In 2017, there was a change in the ordering system for stores, which is related to the change of the distribution strategy from push to pull. Before that, the goods were pushed out of the Logistics Centre as soon as possible and sent to individual stores to reduce the inventory in the Centre. However, this system meant that goods were in stores, and at the same time there was no space for goods that could sell faster. Currently, clothing is shipped to stores as needed. The IT system performs a detailed analysis of sales of individual models in a given store. Shipments of goods from the Logistics Centre are controlled by the actual demand, thanks to which the types of clothing in stores are now better adjusted to the market needs.

The change in the stocking system has improved the adjustment of stocks in stores to the demand, but unfortunately it has influenced an increase in the inventory level in the Logistics Centre. As a result, there was a shortage of space and it was necessary to rent additional warehouses. Presently, the major warehouse stocks are in the Centre and not in the stores. Until the warehouses have been expanded, LPP S.A. will still have to rent warehouse space.

The described model of the supply chain is presented in Figure 2. It is a model with:

- a leader mainly involved in the design and distribution of clothing;

- mass production;

- the push flow between manufacturers and the Logistics Centre, and the pull between the Logistics Centre and stores;

- major warehouse stocks - in the Logistics Centre; 
- the major part of manufacture located in countries with low production costs in South-East Asia;

- distribution in the company's own stores throughout Poland and in many other European countries.

Similar models are also used by other large Polish clothing companies, such as the Redan Capital Group.

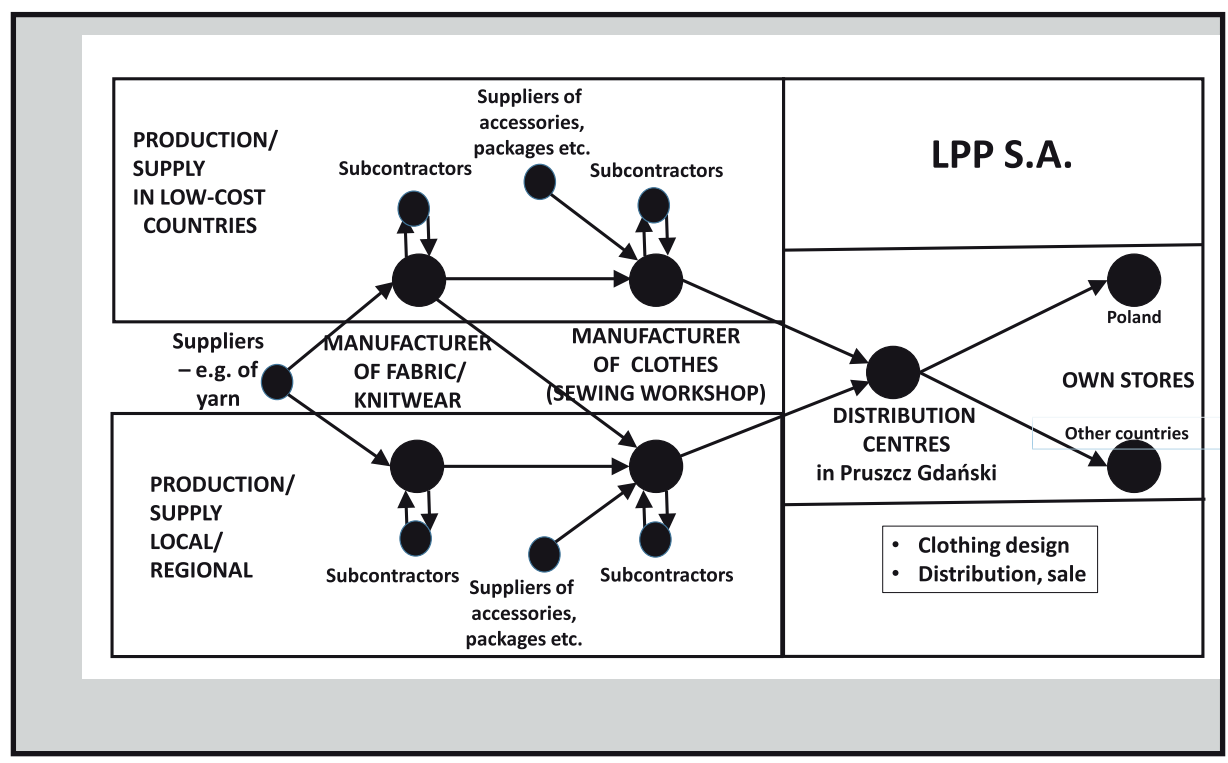

Figure 2. Supply chain model in the clothing industry in mass production with a leader ordering production outside on the example of LPP S.A.

Source: (own elaboration)

\section{A supply chain model in individualized production with a manufacturing outsourcing leader on the example of Macaroni Tomato ${ }^{3}$}

Macaroni Tomato was established in 2012. It sells exclusive men's clothing mainly suits, but also jackets and shirts, sewn according to the company's own design and sold under the company's own brand. Also ties, scarves and other accessories imported from Italy are also sold under the company's own brand, while - shoes are sold under a foreign brand. The manufacturing systems for suits sold by Macaroni Tomato are as follows:

- MTM (Make To Measure). It is created for a specific customer already at the design stage. The process of creation begins with taking measurements and selecting the fabric and accessories by the customer (buttons, lining). The time from taking the measurements to the delivery of a sewn though unfinished suit

3 Based on information obtained at Macaroni Tomato in December 2017. 
is about 4 weeks. Then another try-on takes place. The suit is then tailored by a company based in Warsaw, what lasts for approximately 1.5 week. The share of these suits in the company's sales accounts for about $40 \%$.

- MTO (Make To Order). Suits are sewn to an order of a specific customer, from materials selected by the customer (fabric, buttons, lining), but according to a typical pattern. This is recommended for customers who look well in standard suits. These suits also have a share of about $40 \%$ in the sales.

- RTW (Ready To Wear). These suits are sewn into stock, in larger quantities, in typical sizes and from typical materials. They are stored in the store and sold 'from the hanger'. Their share in the total sales is about $20 \%$.

Most products are therefore sewn for a specific customer - MTM or MTO. Therefore, these products are individualized.

Macaroni Tomato designs suits, however, the process of sewing is outsourced. Since 2016, they have worked with one Polish manufacturer, sewing about $90 \%$ of their clothing. In addition to the Polish manufacturer, Macaroni Tomato also works with an Italian manufacturer. In Italy, about $10 \%$ of products are sewn in the MTM system only. The Polish manufacturer sews in the MTM, MTO and RTW systems.

Macaroni Tomato's main raw material for the manufacture of suits, jackets and shirts are Italian fabrics. They are bought in 2 systems:

- A 'wholesale' system - buying whole bales of selected, typical fabrics, ordered in Poland through agents, but manufactured in Italy to order. Such an order is carried out for about 3 months as it takes so much time to manufacture the fabrics. One bale of material usually suffices for sewing 15-18 suits. Fabrics in this system are delivered several times a year. These fabrics are therefore purchased to stock. Larger stocks are kept for better rotating fabrics, smaller ones - for worse. At Macaroni Tomato, 60-70\% of fabrics are purchased in this way.

- 'The coupon system' - ordering less typical materials for a specific suit ordered by the customer. Therefore, in this system, it is not whole bales of material $(50-60 \mathrm{~m})$ that are purchased, but only as much as is needed (cut length). Fabrics are bought from large companies, which sell fabrics in small quantities. The price of a fabric ordered in this system is 3-4 times higher, but it takes about 3 days to complete an order. 30-40\% of fabrics are bought in this way. This system is only used for tailored suits (MTM). Sewing from a coupon in the MTO system would be unprofitable due to the fact that the largest component of the suit price is the cost of fabric, and suits sewn in the MTO system are much cheaper than those made in the MTM system.

The purchased fabrics are transported by a courier company directly to the manufacturer - a company that sews suits.

The described supply chain model is presented in Figure 3. It is a model with individualized production (mainly MTM and MTO) and a leader commissioning production outside, locally (in Poland) and regionally (in Italy), exclusively from Italian materials. In the case of suits sewn in the MTM system, the pull type flow is between the manufacturer of the fabric and the sewing workshop, as well as between the sewing workshop and the store, so there are no stocks in a warehouse or in a sewing factory. In this case, the main warehouse stocks in a supply 
chain are stored by the fabric manufacturer which sells them in the coupon system. In the case of MTO, suits are manufactured from previously purchased materials, therefore, the pull type occurs on the section between the sewing factory and the store only. Therefore, the main warehouse stocks are in the sewing factory where materials are stocked. However, in the case of suits sewn in the RTW system, the flow is of the push type on the whole-length and stocks of ready suits are kept in the store.

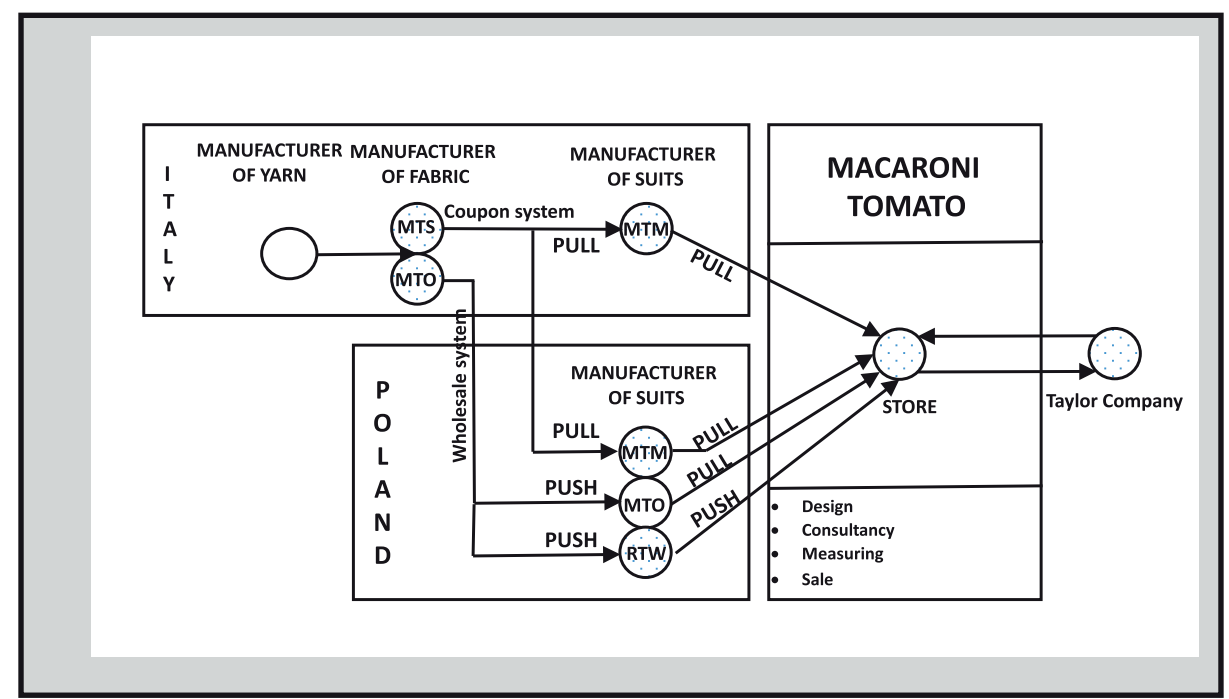

Figure 3. The supply chain model in individualized production with a manufacturing outsourcing leader on the example of Macaroni Tomato

Source: (own elaboration)

\section{Supply chain model for mass production with the manufacturer as the leader on the example of Unikat ${ }^{4}$}

Unikat, Civil Partnership, is a Polish manufacturer of women's lingerie, sewing products according to their own designs and selling them under their own brand. The company has operated since 1995. Currently, it employs approx. 50 people, 35 of whom work directly in the manufacturing department. However, the company does not have its own stores.

It takes about 6 months to design a collection. New collections are created twice a year. Sewing a new collection starts about a month before the sale begins. Catalogues are delivered to stores by sales representatives. If the ordered goods are in stock, they are shipped on the second day. If a shape or a size is missing, Unikat will manufacture it, however, it can take even up to a month to fulfil such an order.

Logistic operators organize the transport of ordered goods to stores. Products are sold in several hundred stores throughout Poland. These are stores that also sell

\footnotetext{
4 Based on information obtained at Unikat in November 2017.
} 
underwear of other brands. Information from the market (from stores) is obtained through visits of sales representatives and through telephone and e-mail contacts when placing orders. Each store is visited once a month by a sales representative who collects orders in stores.

Most of the manufacturing materials are imported from Italy and Switzerland. Some of the materials are also purchased in Poland from importers. The delivery time of materials for manufacturing is 3 to 6 months.

Large stocks are kept in the company's warehouse:

- finished products - rotation of these stocks is 3-4 months or even more;

- work in progress (interoperational stocks, which results from the way in which the manufacturing process is organized and from the human factor - high absenteeism);

- materials and additions for manufacturing (stocks of most materials are maintained for 1-2 manufacturing batches.

Products are sewn in batches. A typical production batch sewn before the season is 50 pieces from each of the thirty sizes. Sewing usually lasts for about 2 weeks. Such a batch does not block the production capacity for too long, but it allows examining the interest of customers in a given model. Later, as the stocks run out, the missing sizes are sewn.

The described supply chain model is presented in Figure 4. It is a model with mass production where the manufacturer plays the role of the leader, selling products in foreign stores throughout Poland. Suppliers of materials are located abroad (Italy, Switzerland), the order execution period is long. Finished products are manufactured mainly on the basis of forecasts and not actual demand. There is no current information from stores - hence, stocks of finished products in the company's warehouse are very large.

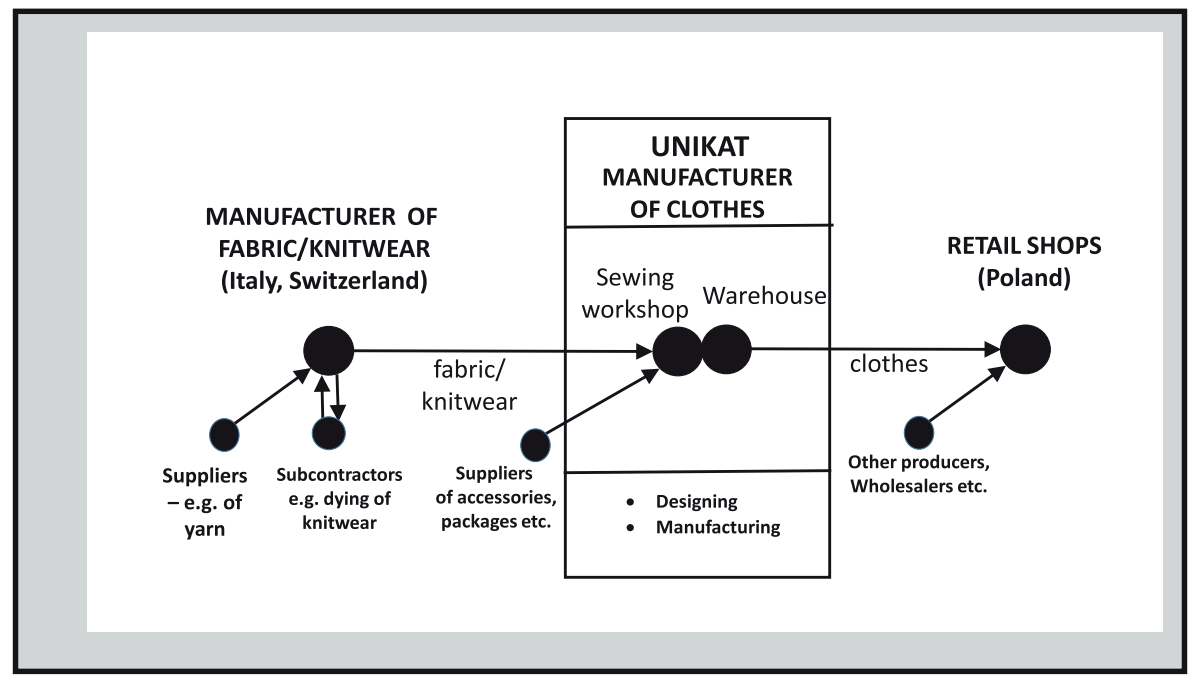

Figure 4. Supply chain model in mass production, with the leader as the manufacturer of clothes, on the example of Unikat

Source: (own elaboration) 


\section{Supply chain model in individualized production with the manufacturer as the leader on the example of Keia ${ }^{5}$}

Keia is a small manufacturer of specialist, mainly medical cosmetic and protective clothing based in Szczecin, operating in the West Pomeranian region since 2007. The company's customers are both institutions (e.g. hospitals, clinics, beauty stores), as well as individuals (e.g. students of medicine, nurses).

The company sews clothes mainly on individual orders, according to its own unique design or according to the client's design; it also designs and sews clothes for oversized or undersized people. The original collection of clothing is presented at exhibitions and medical fashion shows. The product range is wide, and typical sizes are treated only as a starting point in the course of the sewing process of a product for a specific person - clothing is sewn for a specific customer.

Measurements are taken from each person for whom the clothes are sewn in the company - thanks to this, the clothes fit well and the company saves on the costs of corrections, while maintaining the principle of quality management'do everything right the first time'. The time of completion of small orders (up to 10 items) is short (up to 48 hours), while a large order, such as medical clothes for employees of a hospital takes about a month.

The goods are manufactured on a specific order. After the order is accepted, the material requirement is calculated and the necessary components are ordered and delivered on the next day. When the garments have been sewn, they are shipped to the customer.

A certain, very small portion of the production, typical sizes and styles, is sold 'from the hanger' - thus, it is in stock in the company's store. However, the main portion of the production is regulated by the actual demand - it is a pull type flow, both between the manufacturer and the customer, as well as between the supplier and the manufacturer. Therefore, stocks of both finished products and materials are very small.

The company makes free alterations and repairs. Also, customers, who buy typical sizes 'from the hanger' online or in the company's store, have the option of free matching of selected clothes on the spot.

The described supply chain model is presented in Figure 5. It is a model with mainly individual production, low stocks and with the manufacturer as the leader.

5 Based on information obtained at Keia in September 2017. 


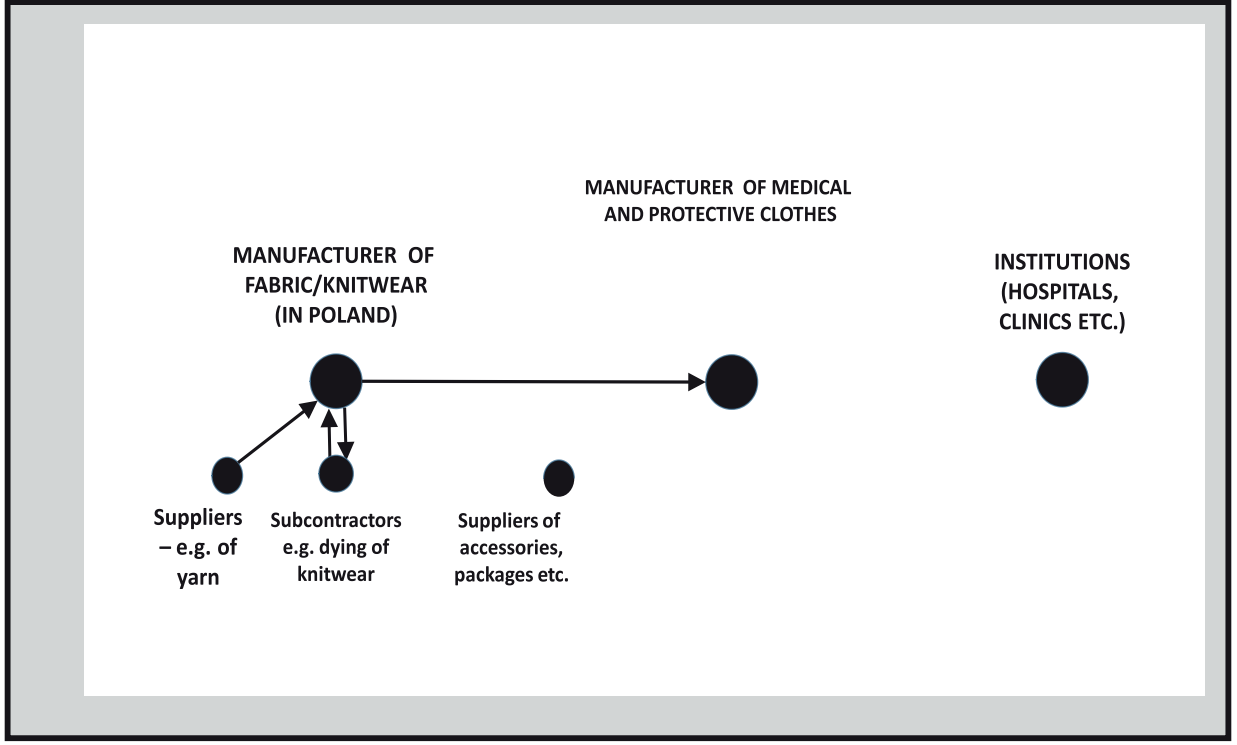

Figure 5. The supply chain model in individualized production with the leader as the manufacturer of clothes on the example of Keia

Source: (own elaboration)

\section{Conclusions}

There are both similarities and differences between the characterized models of supply chains in the clothing industry.

Leaders in supply chains in the clothing industry are often companies that design, distribute and sell products, but do not have their own sewing workshops. In this way, the largest Polish clothing companies, such as LPP S.A. outsource production mainly in countries with low production costs. Although due to the desire to increase the response to changes in fashion, there is a tendency to increase the share of production locally and regionally. The share of air transport from manufacturers located in countries with low production costs to Poland is increasing. The supply chains of the largest clothing companies are characterized by manufacture of standard products. The material flow between manufacturers and the Logistics Centre is of the push type. However, there is a tendency to change the flow from push to pull on the section between the Logistics Centre and the stores - companies are increasingly trying to adapt this flow to the demand. The positive aspect of such adjustment of goods to the demand is a reduction in stocks in stores. However, this entails increasing stock levels in the Logistics Centre. An advantage of using this model are low costs, mainly due to the mass production in countries with low production costs - and thus the ability to compete on price - and a well-developed distribution system, increasing the spatial accessibility of goods. A disadvantage is a long response time to the market needs, but also sensitivity to an increase 
in the transport costs (especially - in maritime transport), exchange rate fluctuations and increasing manufacture costs in Southeast Asian countries.

Supply chain leaders in the clothing industry are sometimes small companies that do not have their own sewing workshops that design and sell products, such as Macaroni Tomato. Such companies, operating on a small scale, can focus on the individual customer, designing and selling tailor-made clothes, exactly according to the customer's order. As these products are relatively expensive, and customers care about high quality, production is outsourced locally or regionally. The individualized production is associated with shifting the main stocks up the supply chain - e.g. in the case of tailored clothing - to the fabric manufacturer. The waiting time for a finished product is relatively long, the sale price is high, but it is compensated by the high quality of the design and workmanship, exceptional service and the ability to adapt the products to the customer's individual wishes.

The supply chain leader is often also a company with its own sewing workshop, which also designs products. If such companies, like the described Unikat, sew standard products for the warehouse, and they do not have their own stores, they may have problems with obtaining current information from the market, which is associated with the risk of excessive stocks of finished products. However, there is no such risk if production is individualized for a specific customer, as is in the case with Keia. However, the delivery time is longer with larger orders.

The features of a typical supply chain model in the clothing industry in Poland are presented in Table 1.

Table 1. Comparison of supply chain models in the clothing industry in Poland

\begin{tabular}{|c|c|c|c|}
\hline $\begin{array}{l}\text { Supply chain leader; } \\
\text { activities }\end{array}$ & Distribution and sale & $\begin{array}{l}\text { Characteristics } \\
\text { of production }\end{array}$ & $\begin{array}{l}\text { Place of main storage } \\
\text { in supply chain }\end{array}$ \\
\hline $\begin{array}{l}\text { LPP S.A. - design, } \\
\text { distribution and sale }\end{array}$ & $\begin{array}{l}\text { Logistic centre; } \\
\text { network } \\
\text { of the company's } \\
\text { own stores in Poland } \\
\text { and in } 20 \text { other } \\
\text { countries; online sales }\end{array}$ & $\begin{array}{ll}- & \text { Mass } \\
- & \text { Outsourced } \\
- & \text { Mainly - } \\
& \text { in countries with } \\
& \text { low production } \\
& \text { costs } \\
\end{array}$ & $\begin{array}{l}\text { Logistics Centre, } \\
\text { From manufacturers } \\
\text { to the Logistics } \\
\text { Centre - push, from } \\
\text { the Centre to stores - } \\
\text { pull }\end{array}$ \\
\hline $\begin{array}{l}\text { Macaroni Tomato - } \\
\text { design, sale }\end{array}$ & $\begin{array}{l}\text { Own sales store } \\
\text { Online sales }\end{array}$ & $\begin{aligned}- & \text { Mainly } \\
& \text { individualized } \\
& \text { (MTM 40\%, MTO } \\
& 40 \%, \text { RTW 20\%), } \\
- & \text { Outsourced } \\
- & \text { Sewing factories } \\
& \text { in Poland and Italy }\end{aligned}$ & $\begin{array}{l}\text { MTM - at the fabric } \\
\text { manufacturer } \\
\text { MTO - in sewing } \\
\text { workshops } \\
\text { RTW - in the store }\end{array}$ \\
\hline $\begin{array}{l}\text { Unikat - design, } \\
\text { manufacture }\end{array}$ & $\begin{array}{l}\text { Warehouse of finished } \\
\text { products, sales } \\
\text { in several hundreds } \\
\text { of foreign stores, online } \\
\text { sales }\end{array}$ & $\begin{array}{ll}- & \text { Mass } \\
- & \text { Own sewing } \\
& \text { workshop } \\
- & \text { In Poland }\end{array}$ & $\begin{array}{l}\text { Warehouse of finished } \\
\text { products }\end{array}$ \\
\hline $\begin{array}{l}\text { Keia-design, } \\
\text { manufacture, sale }\end{array}$ & $\begin{array}{l}\text { Delivery to customers, } \\
\text { company's store, } \\
\text { online sales }\end{array}$ & $\begin{array}{ll}\text { - } & \text { Mainly } \\
& \text { individualized } \\
- & \text { Own sewing } \\
& \text { workshop } \\
- & \text { In Poland }\end{array}$ & Fabric supplier \\
\hline
\end{tabular}

Source: (own elaboration) 
In all the studied supply chains the leader was a company with its own brand, both when the manufacturing was done by the company and when it was outsourced.

\section{Reference}

Cao, N., Zhang, Z., To, K.M., Ng, K. P. (2008), How are supply chains coordinated? An empirical observation in textile apparel businesses, Journal of Fashion Marketing and Management: An International Journal, 12(3), pp. 384-397.

Ciesielski, M. (2009), Instrumenty zarzadzania tańcuchami dostaw [Supply chain management instruments], PWE, Warsaw.

Ciesielski, M., Długosz, J. (2010), Strategie tańcuchów dostaw [Supply chain strategies], PWE, Warsaw.

Hugos, M. (2011), Zarzadzanie łańcuchem dostaw [Supply chain management], Helion, Gliwice. Szymoniak, A. (2010), Logistyka i zarzadzanie tańcuchem dostaw [Logistics and supply chain management], part 1, Difin, Warsaw.

Witkowski, J. (2010), Zarzadzanie łańcuchem dostaw. Koncepcje, procedury, doświadczenia [Supply chain management. Concepts, procedures, experiences], PWE, Warsaw.

https://www.lppsa.com/

\section{Corresponding author}

Beata Milewska can be contacted at: beata.milewska1@gmail.com 